Research Article

\title{
Documentation and Evaluation of an Ancient Paper Manuscript with Leather Binding Using Spectrometric Methods
}

\author{
Rushdya Rabee Ali Hassan, ${ }^{1}$ Mona F. Ali, ${ }^{1}$ Abdel-Gawaad A. Fahmy, ${ }^{2}$ Hayssam M. Ali $\mathbb{D},{ }^{3,4}$ \\ and Mohamed Z. M. Salem (iD ${ }^{5}$ \\ ${ }^{1}$ Conservation Department, Faculty of Archaeology, Cairo University, 12613 Giza, Egypt \\ ${ }^{2}$ Chemistry Department, Faculty of Science, Cairo University, 12613 Giza, Egypt \\ ${ }^{3}$ Botany and Microbiology Department, College of Science, King Saud University, P.O. Box 2455, Riyadh 11451, Saudi Arabia \\ ${ }^{4}$ Timber Trees Research Department, Sabahia Horticulture Research Station, Horticulture Research Institute, \\ Agriculture Research Center, Alexandria, Egypt \\ ${ }^{5}$ Forestry and Wood Technology Department, Faculty of Agriculture (El-Shatby), Alexandria University, Alexandria 21545, Egypt
}

Correspondence should be addressed to Mohamed Z. M. Salem; zidan_forest@yahoo.com

Received 19 March 2020; Accepted 2 June 2020; Published 24 June 2020

Academic Editor: Claudia Crestini

Copyright (c) 2020 Rushdya Rabee Ali Hassan et al. This is an open access article distributed under the Creative Commons Attribution License, which permits unrestricted use, distribution, and reproduction in any medium, provided the original work is properly cited.

\begin{abstract}
The present study presented an integrated analytical approach to the Qur'anic manuscript with leather binding; the multianalyses revealed the degree of degradation for paper and leather in the current manuscript under the study, causing the mapping of treatment. The visual assessment detected yellowness in the internal papers, dark black spots, and advanced erosion in the leather bind. The result detected that this manuscript leads to yellowing and weakness in the properties of paper under the attack of acidity where the $\mathrm{pH}$ of paper reached 5.5. XRD and FTIR analyses of paper illustrated a dramatic decrease of crystallinity index with a notable increase of $\mathrm{C}=\mathrm{O}$ stretching, respectively. The sharp increase of carbonyl group can be used as evidence of oxidation. The microscopic examination also showed that cotton was used in the manufacturing of the paper of the current manuscript, while the leather bind was made from goatskin. In addition, the cellulose and protein bundles were both destructive and disintegrated.
\end{abstract}

\section{Introduction}

Manuscripts were the main preoccupation of those interested in human heritage and history during human civilization. Manuscripts contained the history of humankind from the earliest ages. The papyrus manuscripts appeared in ancient Pharaonic civilization. Ancient Egypt was a source of papyrus, which was exporting it to the rest of the world. The European civilization also introduced the use of animal leathers treated with alkali materials such as lime for the processing of so-called parchment, which recorded the finest decorative writings. At the top of the cognitive pyramid of manuscripts and writings was paper pulp. The achievement is due to the Chinese who succeeded in converting vegetable fibers such as bamboo to an easy-to-write material called "paper" in 105 A.D., and some recent excavations conducted by Chinese University in Hong Kong indicted that paper was known even before this day. The paper lingeringly moved through Chinese merchants to Arab countries such as Iraq, Syria, and Egypt. We find a number of Arabic manuscripts belonging to the $9^{\text {th }}$ century written on paper $[1,2]$. Europeans learnt the method of papermaking almost 500 years after it was known in Samarkand. One of the wonderful things in paper is that it is used from centuries to the present day. Side to side there was the leather as an external cover [3-5].

Many of the studied manuscripts have dealt with paper and its composition, which is not new, but there is an urgent need to explain the chemical composition of the paper and its chemical properties to understand the nature of the substance of the study.

Cellulose is the main component of paper, a normal polymer of glucopyranose units $(\beta-D)$, and these units are 
linked together by the association of $\beta$-glycosidic bond to be finally a long chain and are connected with other hydrogen bond chains which give strength to paper fibers [6].

The cellulose molecules are arranged to be fine bundles, which are eventually assembled to be fibers. There are two systems for arranging the paper molecules: (i) areas with specific crystalline patterns known as crystalline region where cellulosic chains are formed parallel to each other and (ii) areas in which the fibrous are irregular and random or amorphous [7, 8]. These regions are longer than noncrystalline regions. Cellulose is characterized by many properties, but there are properties that are the focus of the attention of the conservator, which explain how the mechanism of damage and aging led to choose the possible treatment and maintenance.

Cellulose is somewhat amorphous, so it has the X-ray diffraction characteristic. The advanced damage under degrading factors can change the crystallization rate. Therefore, the method of ray diffraction can be used to identify the crystallized areas in the paper. In addition, the cellulose is highly sensitive to strong alkaline solutions. The paper loses its strength. It is converted to alkaline cellulose, which easily dissolves into the less stable cellulose hydrates. This information is important for the reagent when handling paper with alkaline solutions such as deacidification or other alkaline solutions during conservation. Paper shall be in safe conditions of acidity $[9,10]$.

Different analytical characterization techniques such as attenuated total reflectance Fourier transform infrared spectroscopy (ATR FTIR) and X-ray diffraction (XRD) were used to elucidate the cellulose's main features, to identify the inorganic composition of the papers, and to study the crystallinity of the samples [11-16].

Dilute acids dissolve the cellulose and the result is the less stable hydrocellulose of the chemical reactions. The cellulose formation shows hydrolysis with water release due to the bonding between the $\mathrm{OH}$ group and the adjacent hydrogen atom. The degradation is also accompanied by the formation of aldehyde and carboxyl groups [17, 18]. Paper is a hygroscopic substance that absorbs water from the surrounding environment, so the temperature and humidity surrounding the paper manuscripts must be adjusted. Cellulose does not exist alone in the composition of paper but there is a natural lignin, which increases the rate of cellulose decomposition especially in sunlight or industrial light, which leads to yellowing of the paper due to the absorption of harmful UV rays [19, 20].

Despite many information on the process of the manuscript industry, the study of archaeological samples answers many questions to both chemists and conservators of manuscripts. Archaeological manuscripts are also exposed to various causes of damage such as atmospheric gases, where oxygen and water vapor make the atmosphere suitable for relaxation and auto-oxidation [21-24].

Sulfur dioxide, as an air pollution gas, is absorbed through the surfaces of manuscripts and high-porous leather and reacts with small quantities of metal compounds, especially iron, which is attached to books, manuscripts, and documents in the form of dust. There is no doubt that the cycle of night and day as well as the succession of industrial lighting tend to auto-oxidation and damage for the collection of books and manuscripts $[25,26]$.

Heat also plays a vital role in the growth of microorganisms. On the other hand, heat accelerates the chemical damage of papyrus, parchment, and paper [27-29]. In addition, adhesives used to bind books and manuscripts such as glue and flour paste lose the strength of the heat paste. In order to understand the nature of the materials involved in the making of manuscripts and leather covers and to determine the current state of damage accurately, there must be an effective analytical strategy based on modern methods and methods in the field of study of manuscripts, which is presented by the current research paper using several analytical methods.

\section{Materials and Methods}

2.1. Description of the Manuscript. A Qur'anic manuscript dating back to the Ottoman period-the tenth century $\mathrm{AH}$ - was selected from the confines of the library of AlAzhar Al-Sharif based on the degree of deteriorations. The following archaeological manuscript was used in the present study: the Qur'anic manuscript (the third quarter of the Holy Quran); the special code for this manuscript is 838 and general code is 88919 .

The Qur'anic manuscript includes 28 sheets written in carbon ink with a leather cover in dark brown color with a number of geometric decorations located in the center of the lashes of the front of the manuscript. In addition to geometric decoration on the four sides in the form of rectangles intertwined within them, a vegetal motif adorns the four sides. The decoration is applied in a pressurized manner on the leather, and its inner writings are framed. The state, engineering registration, and characterization of the manifestations of damage before the restoration methods were described [30, 31].

2.2. Documentation by Visual Assessment and Photography. A Qur'anic manuscript from Turks Gallery at the library of Al-Azhar, Cairo, which is part of the group "Osman Ktekhda" as written on the first page of the manuscript, was analyzed. The dimension of the manuscript is $14.8 \mathrm{~cm} \times 20.8 \mathrm{~cm}$.

2.3. Measurement of the $\mathrm{pH}$. The $\mathrm{pH}$ measurements of paper and the leather were performed using ML1010PH (Misura Line, Romania) with the method of cold extraction, where $1 \mathrm{~g}$ sample of each of leather or paper was soaked in $70 \mathrm{~mL}$ of water for $1 \mathrm{~h} \mathrm{[32]} \mathrm{as} \mathrm{described} \mathrm{in} \mathrm{previous} \mathrm{work} \mathrm{[30].} \mathrm{The} \mathrm{pH}$ meter with a combination electrode was calibrated between $\mathrm{pH}=3$ and 7 at $28^{\circ} \mathrm{C}$.

2.4. Scanning Electron Microscopy (SEM). The manuscript suffered a number of damage due to the poor storage conditions in warehouses that are not equipped with the means of controlling the temperature, humidity, and light, 
which were revealed through the previous stages of documentation. Scanning electron microscopy was used for leather and paper of the manuscript to identify the internal damage of the leather and paper. In addition, a comparison between the archaeological samples and modern samples of leather and paper was undertaken to identify the type of fibers.

Specimens from leather and paper with size of $10 \mathrm{~mm}$ in diameter circular shape were used for SEM examinations. These samples were subjected to sputter coating (Edwards's model S 140A) of gold ions to have a conducting medium. Sputter coated samples were scanned with JEOL Model JSMT20 SEM.

2.5. Cellulose Crystallinity Determination by X-Ray Diffraction Analysis. Crystallinity of cellulose was determined using Compact X-ray Diffract meter System PW 1840. Analytical Equipment (Philips, Eindhoven, the Netherlands) (CU Ka radiation with Ni filter) was used for determining the paper crystallinity. The degree of crystallization of cellulose (crystallinity index) was measured according to the following equation $[30,33]$ :

$$
I_{\text {Crys }}=\left\{\frac{I_{002}-I_{\mathrm{am}}}{I_{002}}\right\} \times 100,
$$

where $I_{\text {Crys }}=$ crystallinity index, $I_{002}=$ intensity at approximately $2 \theta=22.6^{\circ}$, and $I_{\mathrm{am}}=$ intensity at approximately $2 \theta=19^{\circ}$.

2.6. FTIR Spectroscopy Analysis. The IR spectra of samples were measured using Nicolet380 (FTIR) spectrometer with attenuation total reflection (ATR) mode having a zinc selenide crystal, in the range of wavelength $650-4000 \mathrm{~cm}^{-1}$. The IR absorbance frequencies for the samples under test were recorded with an average of 128 scans using a resolution of approximately $4 \mathrm{~cm}^{-1}$.

\section{Results and Discussion}

3.1. Visual Assessment and Photography. Figure 1 illustrates the state of manuscript before the restoration process, where the damage symptoms are visually seen. From the figure, the deep erosion in the outer leather cover, yellowness in the internal papers, and dark black spots on the edges of the manuscript paper were observed. Furthermore, erosion in the outer cover and loss in different parts of the leather as well as the mud smears are clearly shown on leather surface. Those phenomena of degradation indicate the bad conditions, in which the manuscript was kept in addition to the effects of heat, air pollution, and moisture on the paper and leather of the manuscript. Some contaminations (Figure 1) from stains and dusts were noticed on the surface of the original paper. Damages caused by physical factors (such as heat and moisture) appeared in the form of bores, and the tearing of paper fibers and deformation of the paper appearance were also noted.

Furthermore, one of the most important types of documentation and a means to measure the damage, cracks, and insect holes of the manuscript is drawing and documentation of the data using computer software (see Figure 2), where the fine cracks can be easily observed. Some subtle cracks and color changes can only be detected using these programs, which paints an integrated picture of the nature of the damage.

3.2. SEM Examination of Deteriorated Manuscript. SEM images (Figures 3 and 4) showed a complete image of the most accurate details of internal damage on the level of fiber and the extent of the impact of various damage factors on the leather and paper and showed the extent of disintegration and erosion in the internal leather fibers. The manuscript cover was made from goatskin as was detected by comparison with modern sample (Figure 3(a)); the fiber bundles of goat usually are relatively fine and interweaved compactly at a medium angle [31]. The fibers suffered from erosion and separation and damage in the surface layer, in addition to the erosion of fibers themselves (Figures 3(b)-3(e)), and that some bundles are completely destroyed.

Figure 4 shows the SEM images of the manuscript paper. The image can confirm that paper is made from cotton rags (Figure 4(a)). The paper contains some fillers such as calcite recovered from the calcite crystals (Figure 4(b)). Symptoms of erosion in paper fibers, weakness, and clear damage in mineral crystals of fillers are also shown (Figures 4(c)-4(e)). In cultural heritage framework, $\mathrm{CaCO}_{3}$ has been widely used as a filler in ancient paper; therefore, the conservators used it for the deacidification of paper damaged by the presence of iron-gall inks or by interaction with the external environment $[34,35]$. Also, Figure 4(e) shows mycelium and spores of some species of fungi. Deterioration may also be due to the acids and enzymes produced as a metabolic activity of microorganisms [36]. At the same time, fungi play a crucial effect in the disintegration of stones and archaeological materials due to their enormous enzymatic activity [37].

3.3. $\mathrm{pH}$ of Leather and Paper. The $\mathrm{pH}$ of leather recorded was about 4.5 , while it was 5.5 for paper. The results show that the paper needs to be treated for acidity because the degree of acidity of paper is ideally 7.0, and if it is lower than that, as in the manuscript, it will lead to yellowing and weakness in the properties of paper. The leather degree of acidity is somewhat appropriate because the acidity of the leather must be within 4.0-6.0, but the leather can be treated also to provide some kind of future protection against acidity risk $[15,38]$.

3.4. Crystallinity Index by XRD Analysis. Fragments of manuscript paper were analyzed to detect the crystallinity index; the fragments were cleaned for any impurities or dust that affects the results. The XRD peaks are shown in Figure 5. The paper is a semicrystalline cellulose fiber. Therefore, a study of its crystallinity may lead to a more detailed knowledge of the degradation process. XRD results show that there are noticeable differences in the amorphous and crystalline regions in the paper under effect of damage factors; cultural heritage objects are subject to the influence 


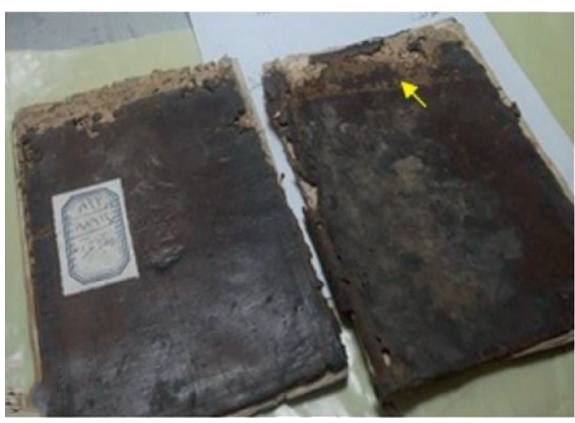

(a)

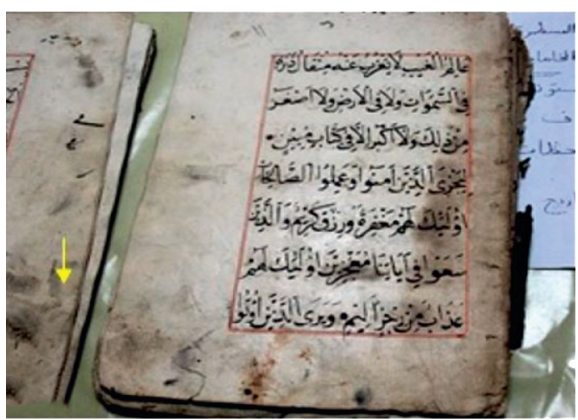

(c)

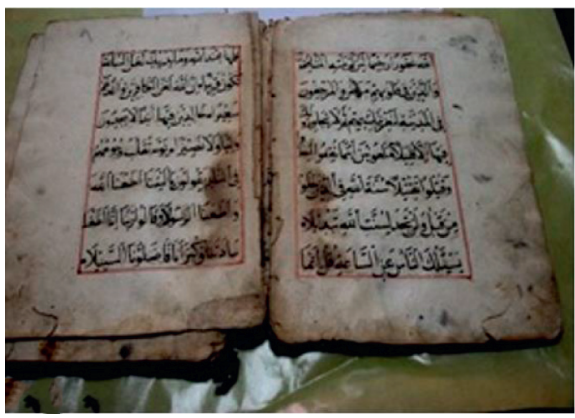

(e)

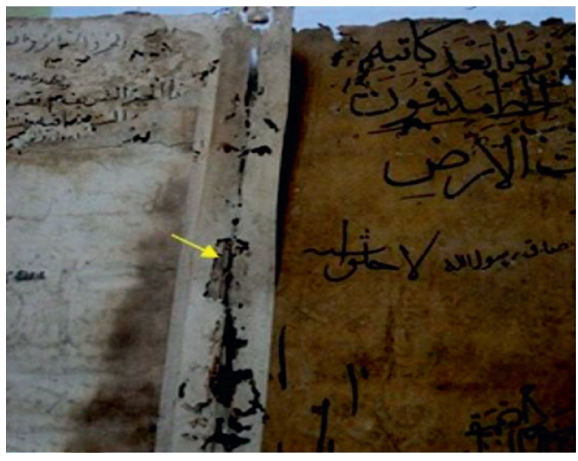

(g)

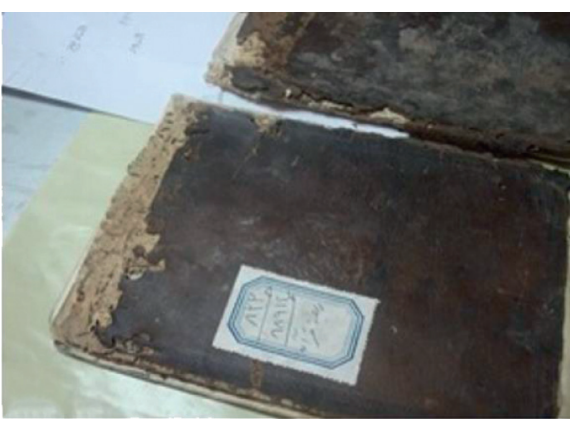

(b)

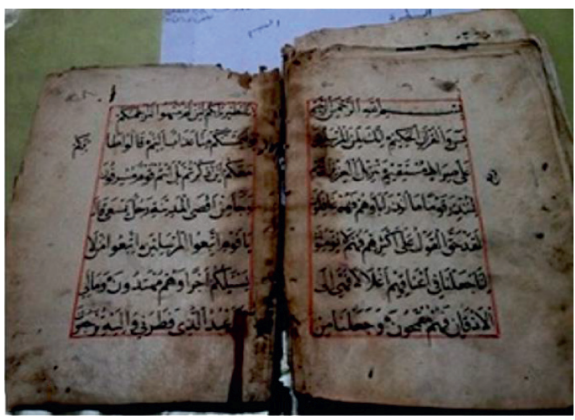

(d)

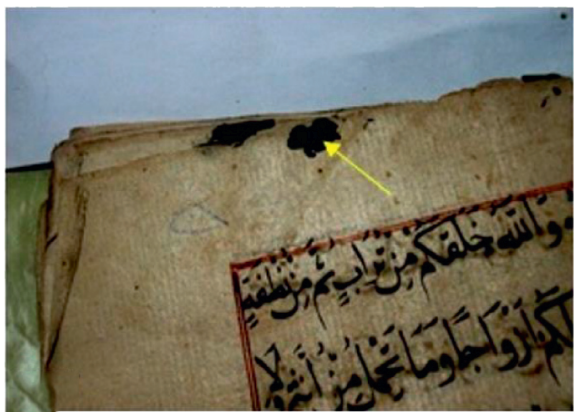

(f)

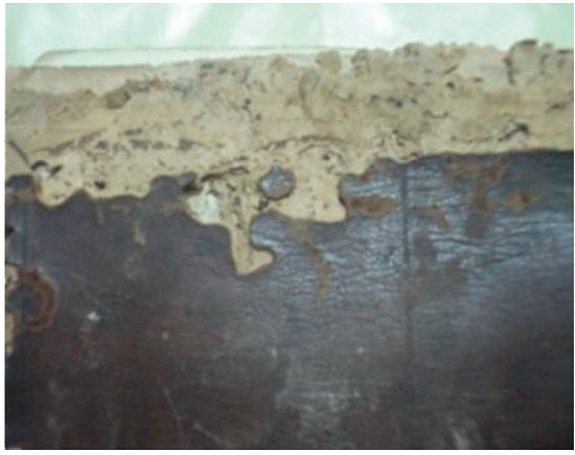

(h)

FIGURE 1: The various damage aspects of the manuscript no. 833. (a) Erosion in the outer cover and loss in different parts of the leather with different mud smears on leather surface. (b) Corrosion in the leather. (c) Patches of soot scattered in the pages of the manuscript. (d) The obvious acidity on the heel of the manuscript and the color and yellowness in the internal papers. (e) The scars in the inner paper. (f) Dark black spots on the edges of the manuscript paper appearing in more than one place in the manuscript. (g) Erosion in paper from the heel area of the manuscript, as indicated by the arrow in addition to the large erosion in the contact areas of the LT. (h) The deep erosion in the leather and paper lining and manuscript.

of environmental parameters, i.e., light, temperature, and moisture, which cause different structural changes on the materials. The long-term exposure to variable conditions changes the structure and properties of the materials. As a result of those, the fibers become less amorphous [39]. The degree of crystallinity in native cellulose records about 

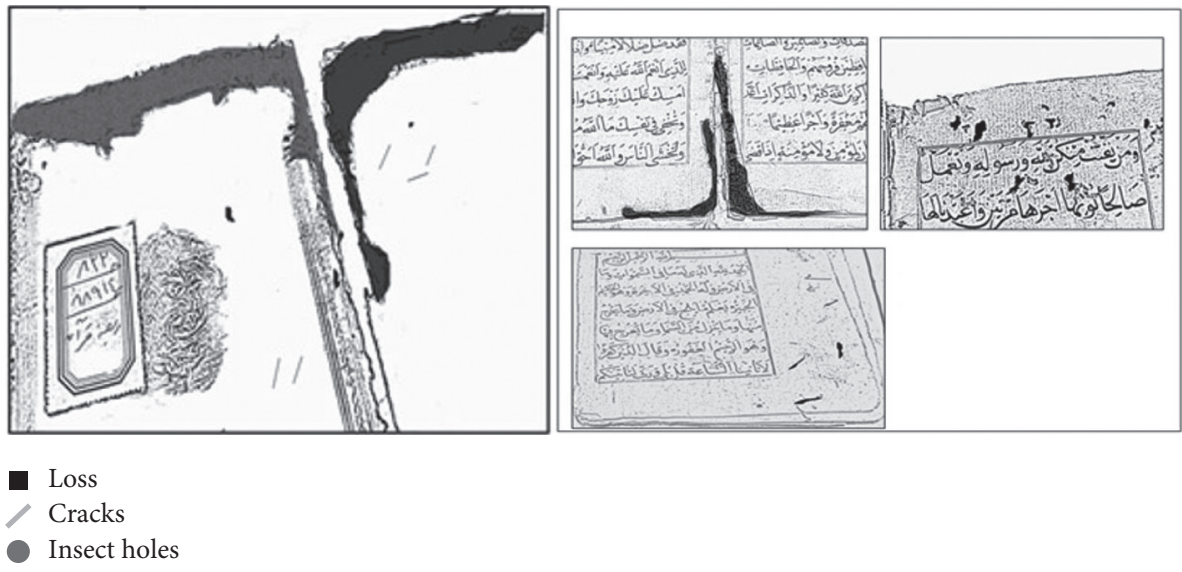

Figure 2: Documentation of the leather cover of manuscript on photoshop.

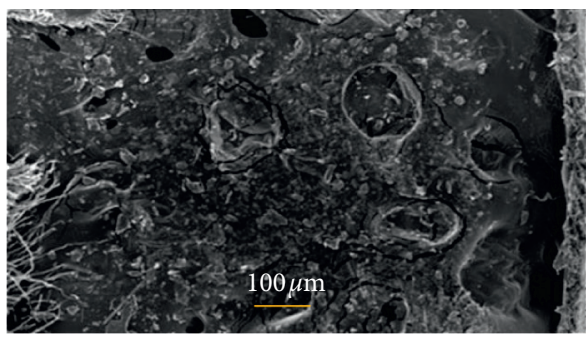

(a)

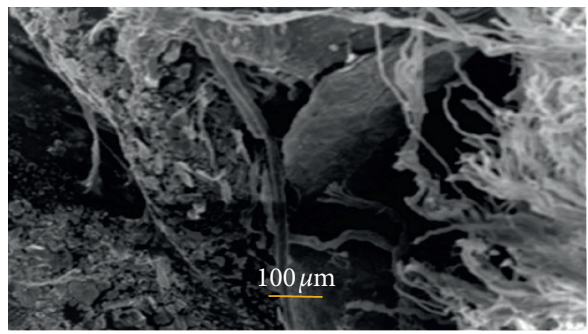

(c)

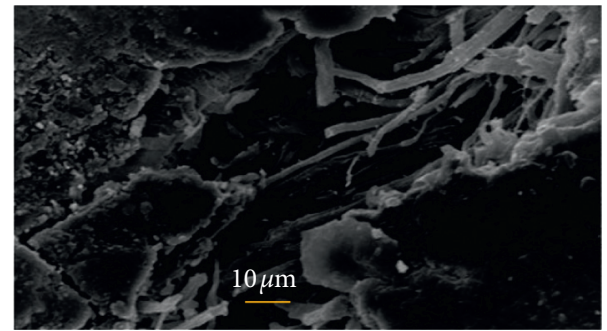

(b)

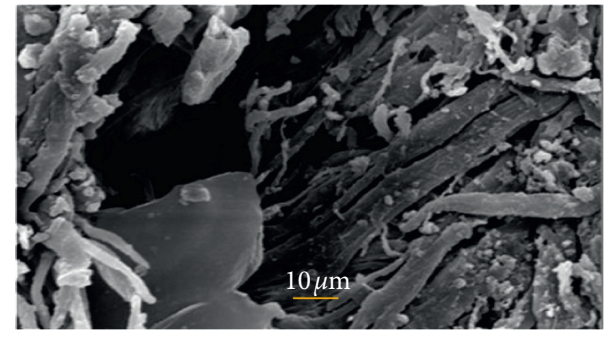

(d)

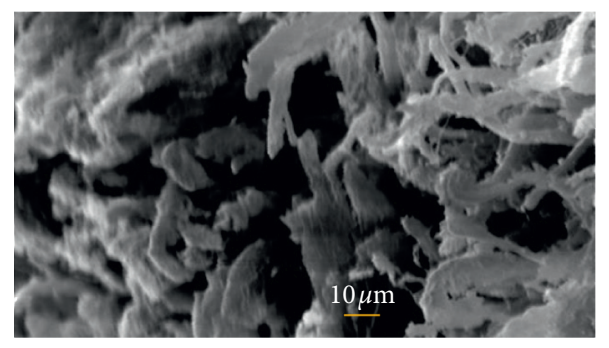

(e)

FIGURE 3: SEM images of leather binding. (a) The superficial appearance of the leather, which is very similar to the surface of goat leather. (b) Clear cracks in the surface of the leather. (c) Corrosion and insect holes. (d, e) Erosion of the surface layer and weakness of the leather fibers in general.

$60-90 \%$ according to the type of source of cellulose where the cotton cellulose reaches about $85 \%$ while this value reduced in case of flax or wood. As shown in Figure 5, $I_{\text {Crys }}=((3.26-0.682) / 3.26) \times 100=79.00 \%$, and this result reveals a dramatic decrease in $I_{\text {Crys }}$ for paper. Therefore, the rigidity of cellulose fibers increases and their flexibility decreases with decreasing ratio of crystalline to amorphous regions.
3.5. XRD for Ink. A preliminary chemical test was undertaken to identify the ink type; the test showed that the ink was not affected by $5 \%$ solution of iron and potassium cyanide with $1 \%$ hydrochloric acid, which proves to be carbon ink. A fraction of the paper containing ink residues was analyzed using X-ray diffraction and showed that the carbon ink is composed of graphite particles (Figure 6). 


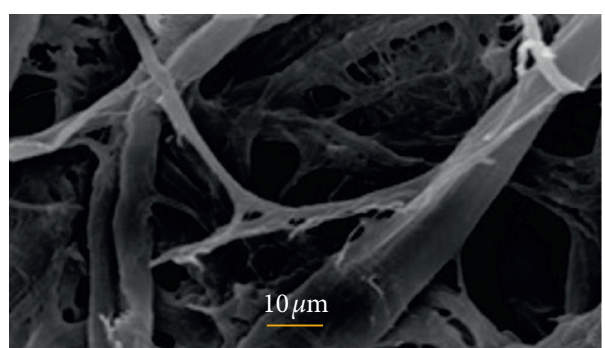

(a)

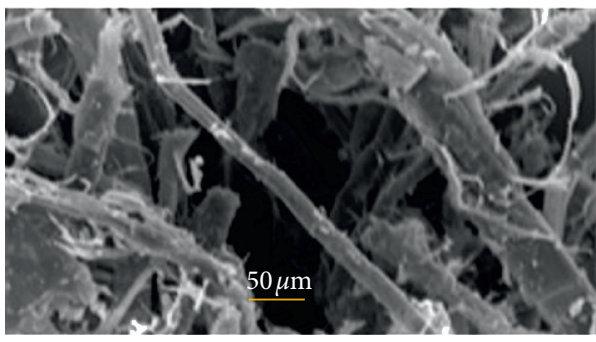

(c)

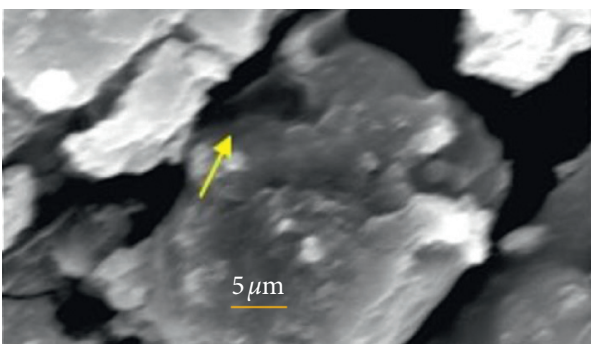

(b)

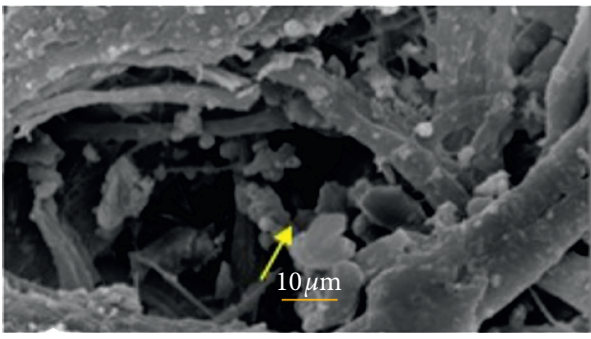

(d)

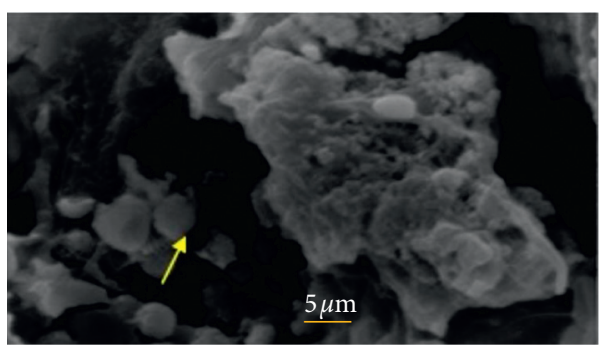

(e)

FIGURE 4: SEM images of surface appearance of a sample of the inner manuscript paper. (a) The surface appearance of the paper, whose fibers are near the pulp fibers of the cotton core. (b) The fillers in the paper approximating the shape of the calcite crystal (calcite in the papermaking process). (c) The shape of a cotton fiber and its distinctive cylindrical shape. (d, e) Erosion and weakness of paper fibers with disintegration in fibers.

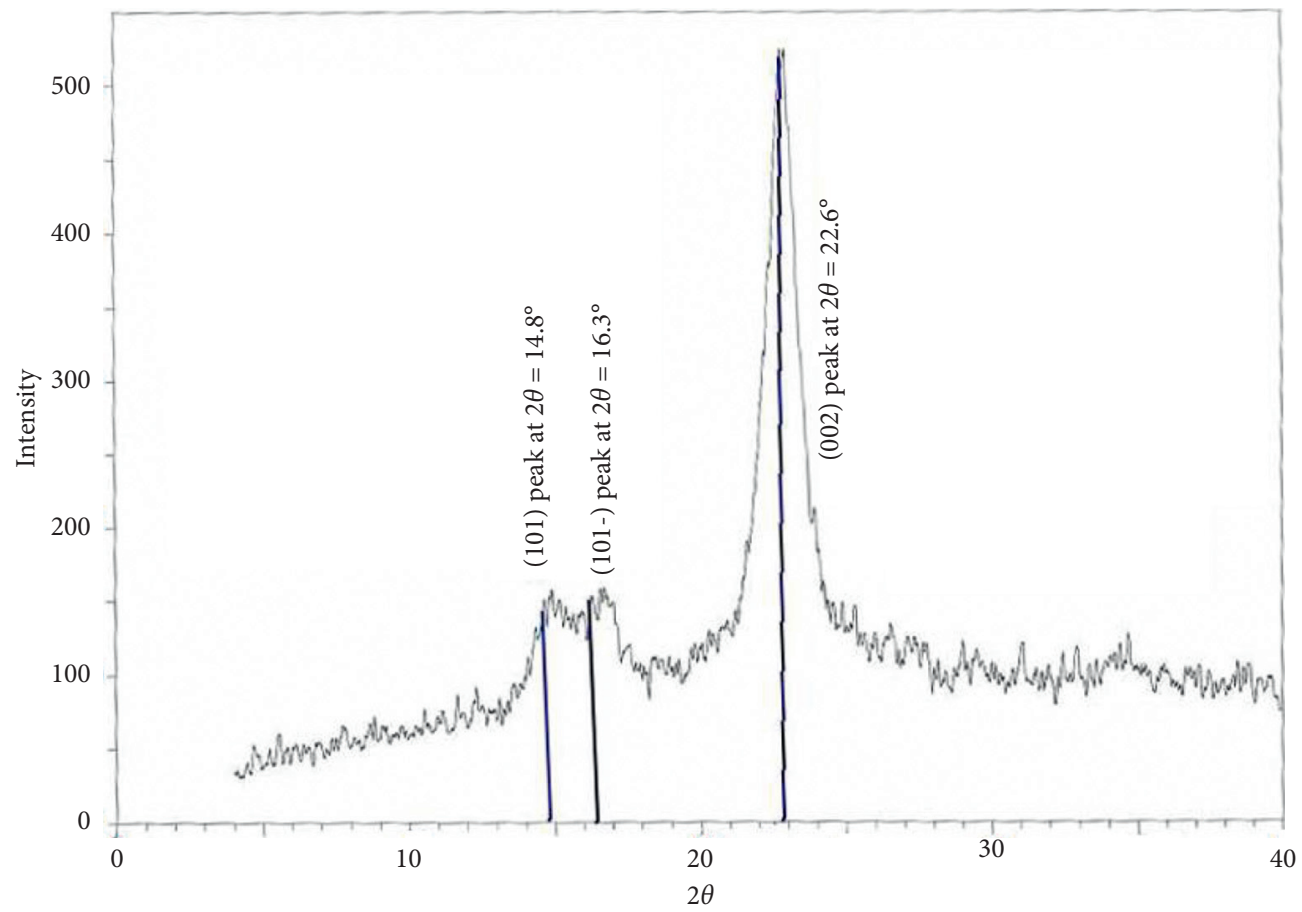

FIGURE 5: X-ray diffractograms of paper. 


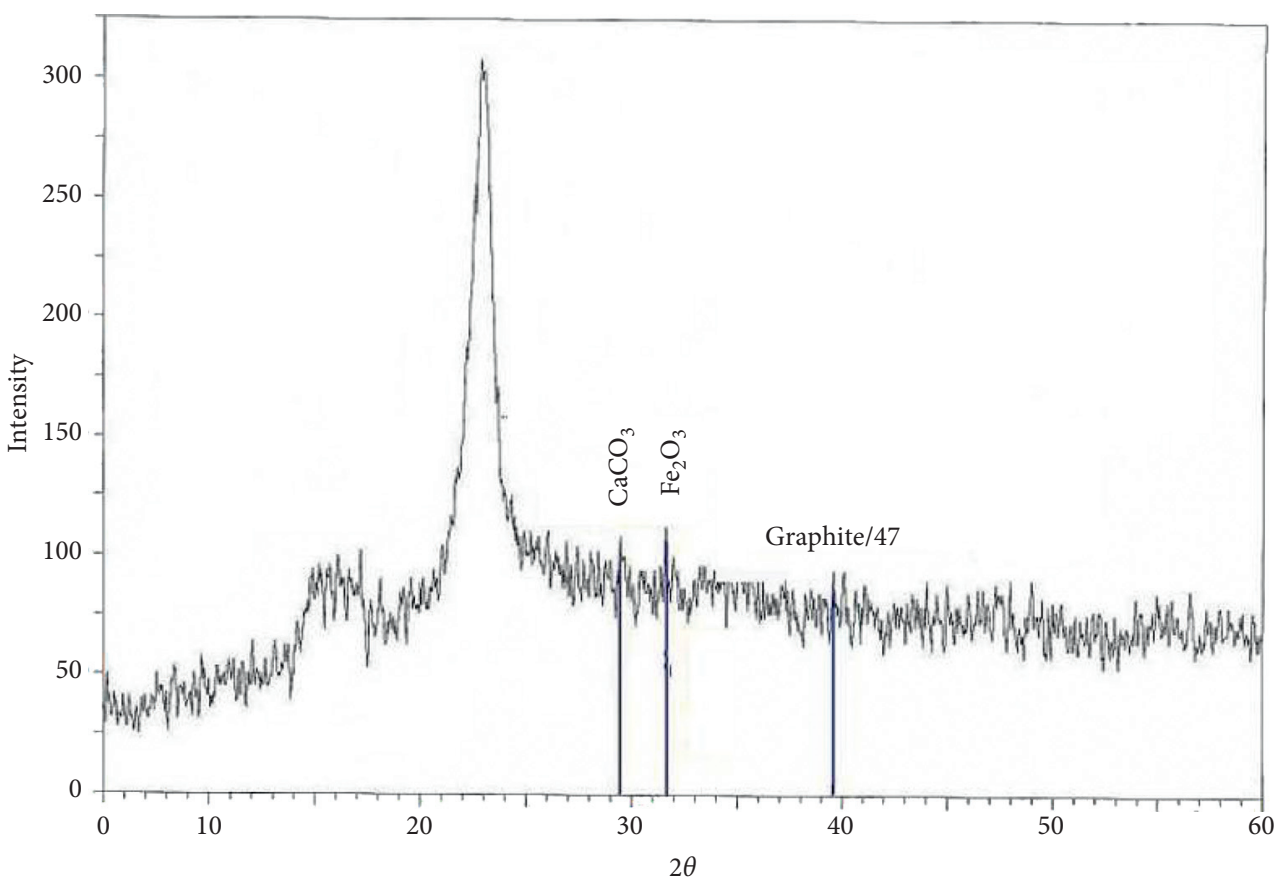

FIGURE 6: XRD pattern of ink confirmed that ink composed the graphite particles.

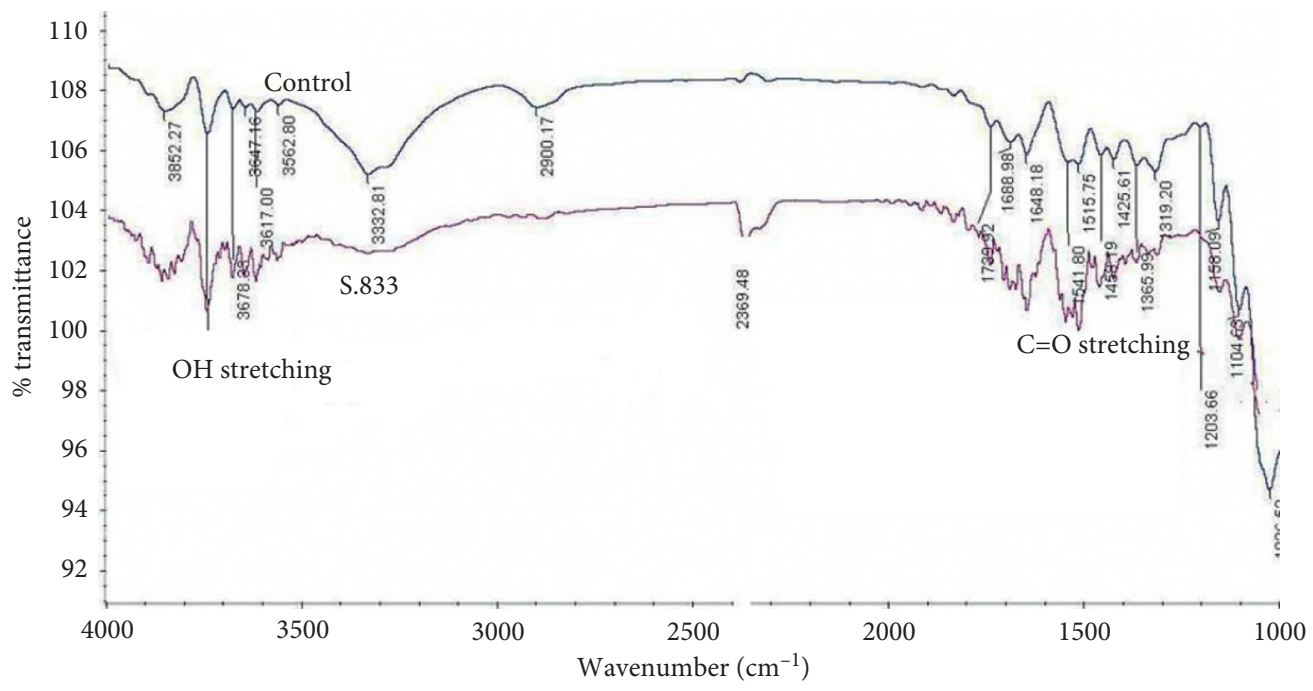

FIGURE 7: FTIR spectra pattern of the paper compared with a modern standard paper.

Figure 6 shows that the ink was a carbon ink (graphite). Previously, the black pigment was almost exclusively identified as carbon in the form of soot, charcoal, or bone black [40-42]. The carbon ink has many advantages such as particles do not fade over time even when exposed to light, chemicals, or when bleached because carbon is chemically stable but carbon ink has a tendency to smudge in humid environments and can fade.

As the examination shows, there are compounds that give important information about the manuscript, including calcium carbonate (chalk), which is used as a filler, which helps in weighting the paper and protects it from the effects of acidity [43]. Hematite impurities usually exist with fillers and have been shown in a number of archaeological specimens that are analyzed [44].

3.6. FTIR Spectra of Paper and Leather. Figure 7 shows the results of paper analysis using FTIR. The analysis was used for the paper and leather sample of the manuscript to identify the nature of the damage and compare their results with modern samples on the level of paper $[45,46]$. Paper is also characterized by a number of groups, including hydroxyl absorption group of $\mathrm{CH}_{2}-\mathrm{OH}$ stretching in area at $3300-3400 \mathrm{~cm}^{-1}[47,48]$. There is a large ethereal group of $\mathrm{C}-\mathrm{O}$ stretching group in the region of $1000-1300 \mathrm{~cm}^{-1}$, while 


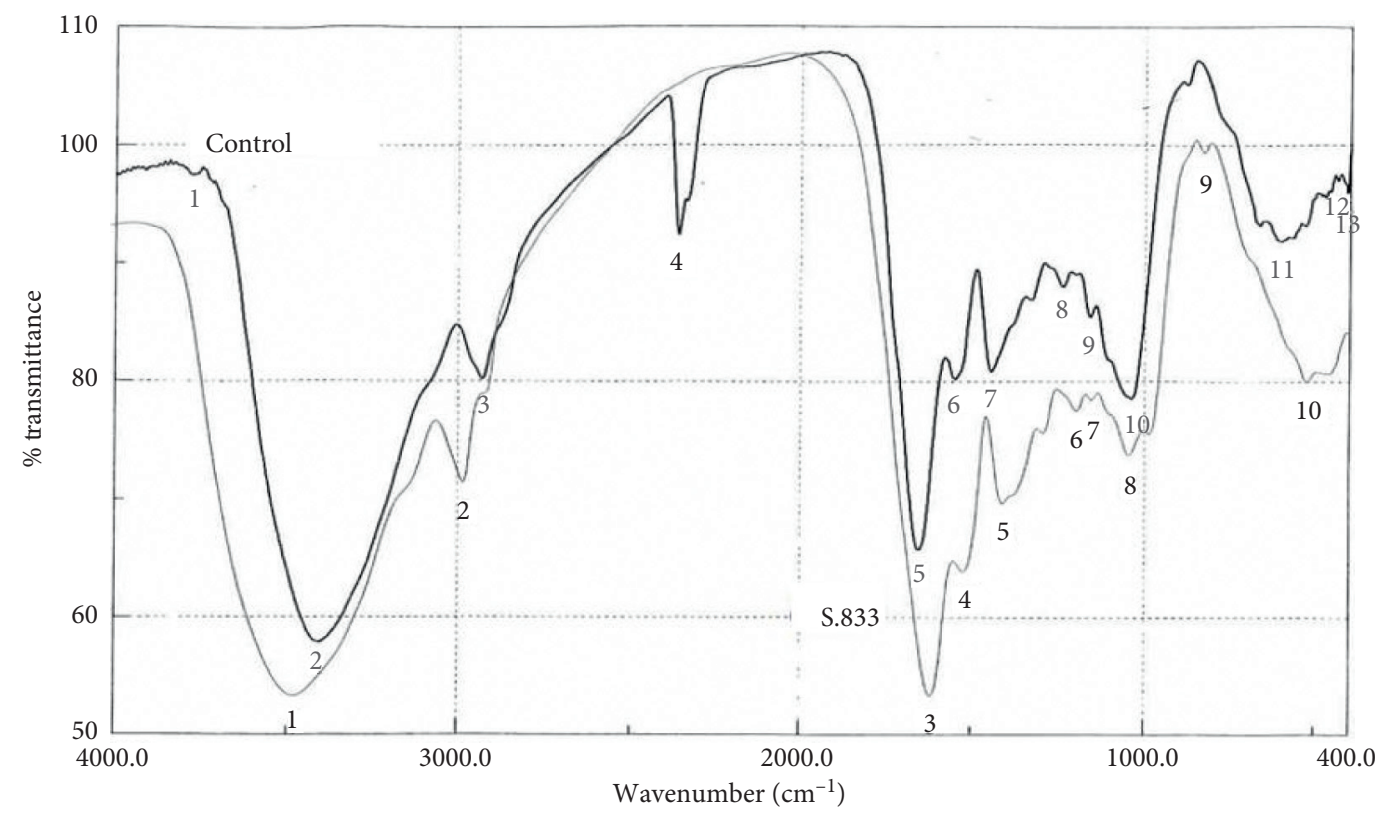

FIGURE 8: FTIR spectra analysis of the leather of the manuscript compared to a standard leather sample.

a spectrum of the archaeological paper shows a change in the chemical composition of cellulose through an increase in some absorption areas of its characteristic groups and a decrease in other areas and formation of new groups $[12,49]$.

There is a significant lack of hydroxyl absorption group $\mathrm{CH}_{2}-\mathrm{OH}$ Stretching at wavelength $3400 \mathrm{~cm}^{-1}$. There is also a significant decrease in the $\mathrm{C}-\mathrm{O}$ stretching group in the region 1300-1200-1100 $\mathrm{cm}^{-1}$ which disappeared sometimes. Also, there is more than a strong carbonic absorption area $\mathrm{C}=\mathrm{O}$ stretching at the region $1600-1575 \mathrm{~cm}^{-1}$, which can prove that cellulose of paper suffers from oxidation [47].

The leather was analyzed on a sample of the external binding and compared with a modern leather sample (Figure 8). The changes in the functional groups were characterized by the protein and appeared clearly in the samples of modern leather. This was not damaged as the standard sample was characterized by the presence of a number of functional groups of leather protein and the most important was $\mathrm{N}-\mathrm{H}$ stretching band at wavelength $3200-3400 \mathrm{~cm}^{-1}[15,37,50] . \mathrm{C}=\mathrm{O}$ stretching band at wavelength $2800-3100 \mathrm{~cm}^{-1}$, C-N-H bending band at wavelength $1500-1565 \mathrm{~cm}^{-1}$, and $\mathrm{C}-\mathrm{H}$ bending at wavelength $1300-1480 \mathrm{~cm}^{-1}$ were found.

There have been changes in these groups in the archaeological sample, where there has been a lack of absorption of a large number of groups such as N-H stretching band at a wavelength of $3404 \mathrm{~cm}^{-1}, \mathrm{C}-\mathrm{N}-\mathrm{H}$ bending band at a wavelength of $1553 \mathrm{~cm}^{-1}$, and $\mathrm{C}=\mathrm{O}$ stretching band at wavelength $2930 \mathrm{~cm}^{-1}$. These changes indicate the role of damage and the disappearance of bonds in the peptide chain and the occurrence of rupturing in the hydrogen bonds that connect the secondary structure of the leather. Heat, as a damage factor, increases the movement of molecules, resulting in the increase of the absorption peak, and shifted to the right in the chart until it was completely disappeared because of breaking the bond [51].

\section{Conclusions}

In the present study, different spectroscopic analyses were used to investigate and characterize the archaeological manuscript of a Qur'anic manuscript dating back to the Ottoman period - the tenth century AH. Visual observation showed various damage aspects of erosion found in the bookbinding leather of manuscript as well as inside the papers of the manuscript. SEM images of the manuscript paper showed the symptoms of erosion in paper fibers, weakness, and clear damage in the paper board. The XRD peaks confirmed the sharp decrease in the crystallization values of paper under effect of damage factors; furthermore, the Arabian artists used calcite which was mixed with iron impurities as a filler material for Arabic paper. FTIR spectra characterized the leather by the presence of a number of functional groups of leather protein which were affected notably under effect of damage.

\section{Data Availability}

The data used to support the findings of this study are included within the article.

\section{Conflicts of Interest}

The authors declare that they have no conflicts of interest.

\section{Acknowledgments}

This research was funded by King Saud University (RSP2020/123), Riyadh, Saudi Arabia. 


\section{References}

[1] B. F. Benz, L. López Mestas, and J. Ramos de la Vega, "Organic offerings, paper, and fibers from the Huitzilapa shaft tomb, Jalisco, Mexico," Ancient Mesoamerica, vol. 17, no. 2, pp. 283-296, 2006.

[2] F. Mahdavi, "Paper before print: the history and impact of paper in the islamic world. by Jonathan M. Bloom (New Haven, Yale university press, 2001) 270 pp. \$45.00," Journal of Interdisciplinary History, vol. 34, no. 1, pp. 129-130, 2003.

[3] A. Karpowicz, "Ageing and deterioration of proteinaceous media," Studies in Conservation, vol. 26, no. 4, pp. 59-60, 1981.

[4] A. V. Persikov, Y. Xu, and B. Brodsky, "Equilibrium thermal transitions of collagen model peptides," Protein Science, vol. 13, no. 4, pp. 893-902, 2004.

[5] R. Newman and M. Serpico, "Adhesive and binders," in Ancient Egyptian Material sand Technology, p. 112, Cambridge Universe Press, Cambridge, UK, 2000.

[6] R. R. A. Hassan and W. S. Mohamed, "The impact of methyl methacrylate hydroxyethyl methacrylate loaded with silver nanoparticles on mechanical properties of paper," Applied Physics A, vol. 124, no. 8, pp. 124-551, 2018.

[7] D. Fengel and W. Wegenel, Wood, Chemistry, Ultrastructure, Reactions, Walter De Gruyter, Berlin, China, 1989.

[8] C. John, Preservation of Paper and Textiles of Historical and Artistic, American Chemical Society, vol. II, p. 29, Washington, DC, USA, 1981.

[9] O. Antoinettec, Cellulose: The Structure Slowly Unravels, p. 173, University of Wales, Cardiff, UK, 1996.

[10] A. Aabloo, A. D. French, R.-H. Mikelsaar, and A. J. Pertsin, "Studies of crystalline native celluloses using potential energy calculations," Cellulose, vol. 1, no. 2, pp. 161-168, 1994.

[11] R. R. A. Hassan, "Fourier transform infrared spectroscopy to detect thermal degradation of vegetable and chrome-tanned leather," Spectroscopy Letters, vol. 52, no. 5, pp. 288-296, 2019.

[12] L. Hajji, A. Boukir, J. Assouik et al., "Conservation of Moroccan manuscript papers aged 150, 200 and 800 years. analysis by infrared spectroscopy (ATR-FTIR), X-ray diffraction (XRD), and scanning electron microscopy energy dispersive spectrometry (S. E. M-EDS)," Spectrochimica Acta Part A: Molecular and Biomolecular Spectroscopy, vol. 136, pp. 1038-1046, 2015.

[13] S. Pessanha, M. Manso, and M. L. Carvalho, "Application of spectroscopic techniques to the study of illuminated manuscripts: a survey," Spectrochimica Acta Part B: Atomic Spectroscopy, vol. 71-72, pp. 54-61, 2012.

[14] A. Duran, J. L. Perez-Rodriguez, T. Espejo, M. L. Franquelo, J. Castaing, and P. Walter, "Characterization of illuminated manuscripts by laboratory-made portable XRD and microXRD Systems," Analytical and Bioanalytical Chemistry, vol. 395, no. 7, pp. 1997-2004, 2009.

[15] M. Mansour, R. Hassan, and M. Salem, "Characterization of historical bookbinding leather by ftir, sem-edx and investigation of fungal species isolated from the leather," Egyptian Journal of Archaeological and Restoration Studies, vol. 7, no. 1, pp. 1-10, 2017.

[16] M. F. Ali, M. M. A. Mansour, N. M. Badr, and M. Z. M. Salem, "A study of biodeterioration and chromatic alterations of painted and gilded mummy cartonnage at the Saqqara museum storeroom, Egypt," Archaeometry, vol. 60, no. 4, pp. 845-858, 2018.

[17] D. Klemm, B. Philipp, T. Heinze, and U. Heinze, Comprehensive Cellulose Chemistry, Wiley $\mathrm{VCH}$, vol. 1, p. 47, Weinheim, Germany, 1998.
[18] C. Y. Liang and R. H. Marchessault, "Infrared spectra of crystalline polysaccharides. II. native celluloses in the region from 640 to $1700 \mathrm{~cm}^{-1}$," Journal of Polymer Science, vol. 39, no. 135 , pp. 269-278, 1959.

[19] H. A. Krassig, "Cellulose-structure, accessibility and reactivity," in Polymer Monographs 11, M. B. Huglin, Ed., Gordon and Breach Science Publishers, Amsterdam, Netherlands, 1993.

[20] S. C. Gilmour, Paper Its Making, Me Chanting and Usage, pp. 89-90, The National Association of Paper Merchants, London, UK, 1956.

[21] L. Le, "Panels, paper and paper board form agricultural residues," Food and Agriculture Organization, Rome, Italy, The FAO Annual, Pulp and Paper Capacity Survey, 2007.

[22] S. M. Arora, "Hand book on pulp and paper industries, raw materials required India," 1990.

[23] F. Lina, "Conservation of Chines shadow puppets of Kwok on collection- Funacăooriente," in Proceedings of the ICOM Conservation Committee: Work Groups of Leather and Related Material and Legal Issues, Athens, Greece, April 2004.

[24] E. Halasz-Csiba, "From woolen sheep leather to gilt leather hangings a historical, technical and lexical approach of Basan in France," in Proceedings of the ICOM Conservation Committee Work Groups of Leather and Related Material and Legal Issues, p. 47, Athens, Greece, April 2004.

[25] P. S. Storch, "Curatorial care and the handling of leather materials, part 1: tanned objects," Conservation Notes, vol. 17, pp. 1-4, 1987.

[26] P. E. Guld Beak, Leather its Understanding and Care Nashville, p. 100, American Association for State and Local History, Nashville, TN, USA, 1969.

[27] M. Souckova, "Influence of the environment humidity and of water used in conservation on treatment on external properties of leather and parchment," Leather Conservation News, vol. 14, no. 1, p. 9, 1998.

[28] H. J. Plenderleith, The Preservation of Leather Bookbinding, p. 201, Great Britain the Trustees of the British Museum, London, USA, 1970.

[29] C. S. Tumosa, M. F. Mecklenburg, W. D. Erhardt, and M. H. McCormick-Goodhart, "A discussion of research on the effects of temperature and relative humidity on museum objects," WAAC Newsletter, vol. 18, no. 3, pp. 19-20, 1996.

[30] R. R. A. Hassan, "A "Tafsir AL Khazen" manuscript $\left(17^{\text {th }}\right.$ century AD). a technical study," International Journal of Conservation Science, vol. 6, no. 3, pp. 369-382, 2015.

[31] R. R. A. Hassan, M. F. Ali, and A.-G. A. Fahmy, "Use of SEM, FTIR, and amino acid analysis methods to assess the damage of some historical leather bindings from the xixth century, stored in national archive, Cairo," International Journal of Conservation Science, vol. 9, no. 1, pp. 127-136, 2018.

[32] ISO 6588-1, "Paper, board and pulps-determination of $\mathrm{pH}$ of aqueous extracts-Part 1: cold extraction," 2012.

[33] R. Attalla and D. Vanderhart, "Native cellulose composite of two distinct crystalline forms," Science, vol. 223, no. 4633, pp. 283-285, 1984.

[34] A. S. Ortiz-Miranda, A. Doménech-Carbó, M. T. DoménechCarbó, L. Osete-Cortina, F. Bolívar-Galiano, and I. MartínSánchez, "Analyzing chemical changes in verdigris pictorial specimens upon bacteria and fungi biodeterioration using voltammetry of microparticles," Heritage Science, vol. 5, no. 1, pp. 1-17, 2017.

[35] P. Calvini and A. Gorassini, "FTIR-deconvolution spectra of paper documents," Restaurator, vol. 23, pp. 48-66, 2002.

[36] M. F. Abdel-Haleim, A. A. Sakr, M. F. Ali, M. F. Ghaly, and C. Sohlenkamp, "Characterization of Streptomyces isolates 
causing colour change of mural paintings in ancient Egyptian tombs," Microbiologial Research, vol. 168, no. 7, pp. 428-437, 2013.

[37] S. Scheerer, O. Ortega-Morales, and C. Gaylarde, "Chapter 5 microbial deterioration of stone monuments-an updated overview," Advances in Applied Microbiology, vol. 66, pp. 97139, 2009.

[38] A. B. Strzelczyk, J. Kuroczkin, and W. E. Krumbein, "Studies on the microbial degradation of ancient leather bookbindings: Part I," International Biodeterioration, vol. 23, no. 1, pp. 3-27, 1987.

[39] R. R. A. Hassan, "The restoration of two historic leather bindings according to a new strategy," Journal of the Institute of Conservation, vol. 42, no. 3, pp. 210-225, 2019.

[40] A. M. B. Olsson, T. Calligaro, S. Colinart et al., "Micro-PIXE analysis of an ancient Egyptian papyrus: identification of pigments used for the "Book of the Dead"," Nuclear Instruments and Methods in Physics Research Section B: Beam Interactions with Materials and Atoms, vol. 181, no. 1-4, pp. 707-714, 2001.

[41] L. Lee and S. Quirke, "Painting materials: ancient Egyptian materials and technology," Edited by P. T. Nicholson and I. Shaw, Eds., pp. 104-117, Cambridge University Press, Cambridge, UK, 2000.

[42] B. Wagner, M. L. Donten, M. Donten, E. Bulska, A. Jackowska, and W. Sobucki, "Analytical approach to the conservation of the ancient Egyptian manuscript "Bakai Book of the Dead": a case study," Microchimica Acta, vol. 159, no. 12, pp. 101-108, 2007.

[43] S. Nagashima, M. Kato, T. Kotani et al., "Application of the external PIXE analysis to ancient Egyptian objects," Nuclear Instruments and Methods in Physics Research Section B: Beam Interactions with Materials and Atoms, vol. 109-110, pp. 658-661, 1996.

[44] M. Aru, L. Burgio, and M. S. Rumsey, "Mineral impurities in azurite pigments: artistic or natural selection?" Journal of Raman Spectroscopy, vol. 45, no. 11-12, pp. 1013-1018, 2014.

[45] M. Zotti, A. Ferroni, and P. Calvini, "Mycological and FTIR analysis of biotic foxing on paper substrates," International Biodeterioration \& Biodegradation, vol. 65, no. 4, pp. 569-578, 2011.

[46] H. E. Ahmed and S. S. Darwish, "Effect of museum conditions on historical dyed silk fabric with madder dye," Journal of Polymers and the Environment, vol. 20, no. 2, pp. 596-606, 2002.

[47] M. Schwanninger, J. C. Rodrigues, H. Pereira, and B. Hinterstoisser, "Effects of short-time vibratory ball milling on the shape of FT-IR spectra of wood and cellulose," Vibrational Spectroscopy, vol. 36, no. 1, pp. 23-40, 2004.

[48] R. R. A. Hassan, "Behavior of archeological paper after cleaning by organic solvents under heat accelerated ageing," Mediterranean Archaeology and Archaeometry Mediterranean Archaeology and Archaeometry, vol. 15, no. 3, pp. 141-150, 2015.

[49] T. Łojewski, K. Zieba, A. Knapik, J. Bagniuk, A. Lubanska, and J. Łojewska, "Evaluating paper degradation progress. Crosslinking between chromatographic, spectroscopic and chemical results," Applied Physics A, vol. 100, no. 3, pp. 809-821, 2010.

[50] Y. Liu, S. Kokot, and T. J. Sambi, "Vibrational spectroscopy investigation of Australian cotton cellulose fibres.part 2. a Fourier transform near-infrared preliminary study," The Analyst, vol. 123, no. 8, pp. 1725-1728, 1998.
[51] R. Michele, S. Dusan, and M. James, Infrared Spectroscopy in Conservation Science: Scientific Tools for Conservation, The Getty Conservation Institute, Los Angeles, CA, USA, 1999. 